\title{
Confederal Agreements: A Proposal to Resolve Secession-Related Minority Issues
}

\author{
Hakan Kolçak \\ Dr. Öğr. Üyesi, Recep Tayyip Erdoğan Üniversitesi, Hukuk Fakültesi, hakan.kolcak@erdogan.edu.tr
}

\begin{tabular}{|c|c|}
\hline Article Info & ABSTRACT \\
\hline $\begin{array}{l}\text { Keywords: } \\
\text { Separatist movements, } \\
\text { Secession, } \\
\text { Sovereign statehood, } \\
\text { Confederalism, } \\
\text { Autonomy, } \\
\text { National minorities. }\end{array}$ & $\begin{array}{l}\text { There are various minority-led separatist movements in Europe that seek to transform self- } \\
\text { governing regions into sovereign states. The existing European states are not eager to fulfil } \\
\text { this minority demand, but the growing separatist trends continue to cause numerous } \\
\text { constitutional problems across Europe. The existing states are likely to resolve such } \\
\text { problems in the name of preserving their constitutional orders. According to this article, } \\
\text { confederal settlements would contribute to the resolution of the problems. It is possible for } \\
\text { separatist national minorities to achieve their main aim - i.e. to construct their sovereign } \\
\text { states - via confederal settlements. These settlements would enable secessionist minorities } \\
\text { and their host states to preserve and promote their constitutional links. The protected and } \\
\text { developed links would ultimately urge confederal allies - national minorities and their } \\
\text { parent states - to turn their unions into highly stable federations or unitary states. }\end{array}$ \\
\hline
\end{tabular}

\section{Konfederal Antlaşmalar: Ayrılmaya İlişkin Azınlık Sorunlarını Çözmek İçin Bir} Öneri

\begin{tabular}{ll}
\hline Makale Bilgileri & Öz \\
\hline Makale Geçmişi & Özerk bölgeleri egemen devletlere dönüştürmeyi hedefleyen, azınlık-odaklı pek çok \\
Geliş: 30.09.2020 & ayrılıkçı akım Avrupa'da varlı̆̆ını sürdürmektedir. Mevzu bahis hedefi gerçekleştirmek için \\
Kabul: 30.10.2020 & mevcut Avrupa devletleri hevesli gözükmüyor olsa da büyüyen ayrılıçı eğilimler, Avrupa \\
Yayın: 31.12.2020 & çapında sayısız anayasal soruna yol açmaya devam etmektedir. Mevcut devletlerin kendi \\
Anahtar Kelimeler: & anayasal düzenlerini koruma adına söz konusu sorunları çözmesi ihtimal dahilindedir. Bu \\
Ayrılıkçı akımlar, & çalışmaya göre; konfederal antlaşmalar, bahsi geçen sorunların çözümünde katkı sunabilir. \\
Ayrılma, & Ayrılıkçı ulusal azınlıklar, bu tip antlaşmalar marifetiyle egemen devlet kurmak şeklinde \\
Egemen devlet olma, & ifade ettikleri ana hedeflerine ulaşabilirler. Ek olarak; konfederal antlaşmalar, ayrılıkçı \\
Konfederalleşme, & azınlıklar ve bu azınlıkları barındıran devletler arasında bulunan anayasal bağların \\
Özerklik, & korunmasını ve geliştirilmesini mümkün kılabilir. Korunan ve geliştirilen bağların nihai bir \\
Ulusal azınlıklar. & sonucu olarak; konfederal müttefikler - ulusal azınlıklar ve bu azınlıkları barındıran \\
& devletler - kurmuş oldukları birliklerini istikrarlı federasyonlara yahut üniter devletlere \\
& dönüştürebilir.
\end{tabular}

Atıf/Citation: Kolçak, H. "Confederal Agreements: A Proposal to Resolve Secession-Related Minority Issues", Necmettin Erbakan University Faculty of Law Review, V. 3, I. 2, 2020, 208-232. 


\section{INTRODUCTION}

There are a significant number of active secessionist movements across Europe that are led by territorially concentrated national minorities, including the Catalans and the Scots. ${ }^{1}$ The movements seek to turn minority-dominated autonomous regions, e.g. Catalonia and Scotland, into sovereign states. ${ }^{2}$ The existing European states are unwilling to satisfy this minority demand, but the number of minority-led separatist movements are growing dramatically. ${ }^{3}$ This circumstance would ultimately stimulate the existing states to alter their attitudes towards the demand and accordingly resolve secession-related minority issues in the name of safeguarding their constitutional orders. ${ }^{4}$

This article argues that confederal arrangements would help sovereign states to resolve their secession-concerned minority issues. These arrangements would enable separatist national minorities to achieve their main purpose, i.e. to establish their sovereign states. The arrangements would provide secessionist minorities and their host or parent states with concrete opportunities to construct common unions, enabling them to secure and develop some of their existing constitutional ties. The secured and developed ties would eventually create highly stable federations or unitary states when regional loyalties turn into confederal allegiance built on shared common interests and mutual trusts.

As an interdisciplinary study drawing on the methods of general public law and constitutional politics, this article seeks to scrutinise how sovereign states resolve their secession-concerned minority questions. The article is organised in the following fashion. It initially analyses separatist national minorities. It then examines the basic characteristics of confederal governance. Finally, the article explains how confederal arrangements contribute to the resolution of the aforementioned questions.

\section{Secessionist National Minorities}

The concept of minority refers to groups who find themselves in " a position of relative subordination in a given societal context". ${ }^{5}$ Sheer numerical inferiority is considered as the main reason for subordination.

1 Müller-Plotnikow, Sabrina. "Beyond Catalonia: Separatist Movements in Western Europe", Deutsche Welle, (30.09.2017), $\quad$ https://www.dw.com/en/beyond-catalonia-separatist-movements-in-western-europe/a40761144, (Access-ed on: 24.09.2020); Cetin, Serife. "EU Response on Catalonia Reveals Fears of Separatism", Anadolu Agency, (11.10.2017), https://www.aa.com.tr/en/europe/eu-response-on-cataloniareveals-fears-of-separatism/933025, (Access-ed on 24.09.2020); Henley, Jon / Sheehy, Finbarr / Swann, Glenn / Fenn, Chris. "Beyond Catalonia: Pro-independence Movements in Europe", The Guardian, (27.10.2017), https://www.theguardian.com/world/ng-interactive/2017/oct/27-/beyond-catalonia-proindependence-movements-in-europe-map, (Accessed on: 25.09.2020).

2 Morice, Sarah. "2017 Year in Review: Europe's Secessionist Movements", TRT World, (25.12.2017), https://www.trtworld.com/europe/2017-year-in-review-europe-s-secessionist-movements-13595, (Accessed on: 25.09.2020); Ellyatt, Holly. "If Catalonia Goes Independent, These Places Could be Next", CNBC, (06.10.2017), https://www.cnbc.com/2017/10/06/if-catalonia-goes-independent-these-places-could-benext.html, (Accessed on: 25.09.2020); Raja, Irfan. “Can the United Kingdom Hold its Union?”, Daily Sabah, (21.02.2020), $\quad$ https://www.dailysabah.com/op-ed/2020/02/21/can-the-united-kingdom-hold-its-union, (Accessed on: 24.09.2020).

3 Torres, Diego. "Europe's Separatists Feel Catalan Chill”, Politico, (04.09.2018), https://www.politico.eu/article/cata-lan-chill-for-european-separatist-movements-aland-islands-south-tyrol/, (Accessed on: 26.09.2020); Schreuer, Milan. “Catalan Separatists Want Independence. Who Else?”, The New York Times, (17.12.2017), https://www.nytimes.com/2017/12/17/world/europe/catalonia-independenceeurope.html, (Accessed on: 26.09.2020).

4 Griffiths, Ryan. "Between Dissolution and Blood: How Administrative Lines and Categories Shape Secessionist Outcomes", International Organization, vol. 69, no. 3, 2015, pp. 731-751; Coggins, Bridget. "Friends in High Places: International Politics and the Emergence of States from Secessionism", International Organization, vol. 65, no.3, 2011, pp. 433-468.

5 Kraus, Peter. "Democracy's Challenge: Nordic Minority Politics in the European Context", The Challenge of Minority Integration: Politics and Policies in the Nordic Nations, edited by Peter Kraus and Peter Kivisto, De Gruyter, Berlin 2015, p. 46. 
However, numbers are always connected to other distinct factors concerning cultural, ethnic, linguistic or religious characteristics. Francesco Capotorti takes into account several potential factors and proposes the most widely agreed upon definition of minority as follows: "A group numerically inferior to the rest of the population of a State, in a non-dominant position, whose members - being nationals of the State - possess ethnic, religious or linguistic characteristics differing from those of the rest of the population and show, if only implicitly, a sense of solidarity, directed towards preserving their culture, traditions, religion or language". ${ }^{6}$ This broad approach is embraced by Article 1 of the United Nations (UN) General Assembly Resolution 47/135 on the rights of minorities, which was approved unanimously on 18 December $1992 .{ }^{7}$ Objective and subjective definitional criteria are originated from Capotorti's definition. The objective criteria are those certain features that distinguish a group from the majority, e.g. a distinct culture, ethnicity, language or religion. The subjective criteria are those that provide a group with minority consciousness. ${ }^{8}$

Minorities are classified into two main categories in accordance with the aforementioned criteria, namely (i) cultural minorities and (ii) national minorities. Cultural minorities (immigrants and their descendants) are those who fulfil the objective conditions but fail to satisfy the subjective criteria due to their desire to integrate into the majority culture. National minorities are those who satisfy both objective and subjective criteria. This definition of national minority is recognised by the Parliamentary Assembly of the Council of Europe (PACE). According to Article 1 of the Draft Additional Protocol on the Rights of Minorities to the European Convention on Human Rights (Recommendation 1201 (1993)), national minority is a group of persons in a state who:

a) reside on the territory of that state and are citizens thereof;

b) maintain longstanding, firm and lasting ties with that state;

c) display distinctive ethnic, cultural, religious or linguistic characteristics;

d) are sufficiently representative, although smaller in number than the rest of the population of that state or of a region of that state; and

e) are motivated by a concern to preserve together that which constitutes their common identity, including their culture, traditions, religion or language. ${ }^{9}$

There are two main types of national minorities under the light of the above definition: (i) indigenous peoples and (ii) stateless nations. Indigenous peoples are those whose "traditional lands were overrun by settlers and then forcibly, or through treaties, incorporated into states run by outsiders". ${ }^{10}$ These peoples seek to protect certain traditional ways of life and beliefs whilst nonetheless participating in the contemporary world on their own terms. ${ }^{11}$ Many indigenous peoples, e.g. the Sami in Scandinavia, the

6 Capotorti, Francesco. Study on the Rights of Persons Belonging to Ethnic, Religious and Linguistic Minorities, Official Publications of the United Nations, New York, 1979, p. 96.

7 Declaration on the Rights of Persons Belonging to National or Ethnic, Religious and Linguistic Minorities, 3 February 1992, UN General Assembly Resolution A/RES/47/135, art. 1.

8 Goldman, Olivia. "The Need for an Independent International Mechanism to Protect Group Rights: A Case Study of the Kurds", Tulsa Journal of Comparative and International Law, vol. 2, no. 1, 1994, pp. 45-60. The Protocol was adopted by the PACE on 1 February 1993. It was not endorsed by the Committee of Ministers, preventing the Protocol from entering into force.

10 Kymlicka, Will / Norman, Wayne. "Citizenship in Culturally Diverse Societies: Issues, Contexts and Concepts", Citizenship in Diverse Societies, edited by Will Kymlicka and Wayne Norman, Oxford University Press, Oxford, 2000, p. 20.

11 Levy, Jacob. "Three Modes of Incorporating Indigenous Law", Citizenship in Diverse Societies, edited by Will Kymlicka and Wayne Norman, Oxford University Press, Oxford, 2000, p. 297. 
Aboriginals in Australia and Canada, the Maori in New Zealand and the Inuit in Greenland, try to achieve this goal via self-government, land and special representation rights. ${ }^{12}$

Stateless nations are those who may constitute regionally concentrated minority groups in sovereign states. ${ }^{13}$ Their historic territories "may have been conquered and annexed by a larger state or empire in the past; ceded from one empire to another; or united with another kingdom through royal marriage [or through voluntary agreements aimed at forming a mutually beneficial union]". ${ }^{14}$ These nations typically mobilise along nationalist lines, utilising the language of nationhood to protect and promote their distinct ethnic, cultural, linguistic, religious or other basic characteristics. They intend to enhance their political autonomy in protecting and promoting these characteristics. ${ }^{15}$

The term 'autonomy' derives from the following Greek-origin words: auto (self) and nomos (law or rule). The basic meaning of autonomy is to make one's own laws. In the modern world, the term is used so widely in many branches of science, from theology to philosophy and psychology. It is worth noting that autonomy has numerous meanings and interpretations in the disciplines of constitutional law and political science. Ruth Lapidoth classifies the definitional debate into four main categories: (i) autonomy as a right to act upon one's own discretion in specific matters, whether on an individual basis or via a public body; (ii) autonomy as synonymous to independence; (iii) autonomy as a synonym of decentralisation; and (iv) autonomy as a reference to a (non)territorial unit which enjoys exclusive legislative, executive and/or judicial powers in certain areas. ${ }^{16}$ The fourth concept is defined by many eminent scholars as political autonomy. ${ }^{17}$ There is indeed no consensus upon what political autonomy certainly means as a term of constitutional law. However, it is still possible to make a general definition by paying a particular attention to common points of various relevant definitions: political autonomy is "a means of internal power-sharing aimed to preserve the cultural and ethnic variety, while respecting the unity of a state". ${ }^{18}$ There are three

These rights provide indigenous peoples with a significant degree of political autonomy. For more details on indigenous peoples, see Kymlicka, Will. "The Essentialist Critique of Multiculturalism: Theory, Policies and Ethos", Multiculturalism Rethought: Essays in Honour of Bhikhu Parekh, edited by Tariq Modood and Varun Uberoi, Edinburgh University Press, Edinburgh, 2015, pp. 219-245; Borrows, John. "Landed Citizenship: Narratives of Aboriginal Political Participation", Citizenship in Diverse Societies, edited by Will Kymlicka and Wayne Norman, Oxford University Press, Oxford, 2000, pp. 326-342; Kymlicka, Will. "The Rise and Fall of Multiculturalism? New Debates on Inclusion and Accommodation in Diverse Societies", International Social Science Journal, vol. 61, no. 199, 2010, pp. 97-105; Kymlicka, Will. "Beyond the Indigenous/Minority Dichotomy", Reflection on the UN Declaration on the Rights of Indigenous Peoples, edited by Stephen Allen and Alexandra Xanthaki, Hart Publishing, Oxford, 2011, pp. 183-208.

It is worth noting that some stateless nations would be territorially dispersed, such as the Roma in western European countries. For more details on territorially dispersed stateless nations, see Kymlicka, Will. "The Internationalization of Minority Rights”, International Journal of Constitutional Law, vol. 6, no. 1, 2008, pp. 1-32; Kymlicka, Will. "Categorizing Groups, Categorizing States: Theorizing Minority Rights in a World of Deep Diversity”, Ethnic \& International Affairs, vol. 24, no. 3, 2009, pp. 371-388.

Kymlicka / Norman, pp. 19-20.

Kymlicka / Norman, p. 20.

Lapidoth, Ruth. Autonomy: Flexible Solutions to Ethnic Conflicts, United States Institute for Peace Press, Washington, 1997, pp. 2-15.

17 For such definitions, see Nordquist, Kjell. "Autonomy as a Conflict-Solving Mechanism: An Overview", Autonomy: Applications and Implications, edited by Markku Suksi, Kluwer Law International, The Hague, 1998, pp. 59-77; Ghai, Yash. "Ethnicity and Autonomy: A Framework for Analysis", Autonomy and Ethnicity: Negotiating Competing Claims in Multi-Ethnic States, Cambridge University Press, Cambridge, 2000, pp. 1-26; Hannum, Hurst. Autonomy, Sovereignty and Self-determination: The Accommodation of Conflicting Rights, University of Pennsylvania Press, Philadelphia, 1996; Heintze, Hans. "On the Legal Understanding of Autonomy", Autonomy: Applications and Implications, edited by Markku Suksi, Kluwer Law International, The Hague, 1998, pp. 7-32.

18 Benedikter, Thomas. The World's Modern Autonomy Systems: Concepts and Experiences of Regional Territorial Autonomy, EURAC Institute of Minority Rights, Bolzano, 2009, p. 19. 
main types of political autonomy: (1) personal/cultural autonomy, (2) administrative (local) autonomy and (3) territorial autonomy. ${ }^{19}$

It is theoretically possible to distinguish personal autonomy from its cultural counterpart, but these two autonomy types are almost the same in practice, encouraging us to explain them in a unitary manner. ${ }^{20}$ Personal/cultural autonomy is a type of political autonomy that applies to all individual members of an ethnic, cultural, linguistic or religious community which is mostly, but not always, territorially dispersed. This autonomy "grants a precisely defined set of rights to individuals on the basis of their membership in a particular group". ${ }^{21}$ Personal/cultural autonomy would recognise and safeguard personal rights (e.g. double citizenship, access to educational facilities, etc.), cultural rights (e.g. broadcasting and language rights) and political freedoms (such as a certain number of reserved parliamentary seats). ${ }^{22}$ These rights are generally exercised by a self-administering association of persons. This association would have its selfgoverning representative institutions which do not enjoy legislative powers, and which refer to no particular territory. Historically, the Ottoman Empire granted its non-Muslim inhabitants - mainly Armenians, Greeks and Jews - personal/cultural autonomy through its administrative practise, known as 'the millet system'. ${ }^{23}$

Administrative (local) autonomy is "an expression of decentralisation and sets forth a delegation of certain powers but not includes any legislative powers exercised by locally elected bodies". ${ }^{24}$ This form of political autonomy generally applies to territorially concentrated national minorities. It is much more comprehensive and extensive than personal/cultural autonomy. In administrative autonomies, there are special administrative institutions, (partially) funded by states, in addition to general administrative units (e.g. districts, municipalities and counties). These special institutions are permitted to make secondary laws (decrees and bylaws) in the fulfilment of various tasks, ultimately empowering the residents of administrative units to look after their own (minority-related) matters. A current example of administrative autonomy is that being exercised by the Danish minority in the German city of Flensburg. ${ }^{25}$

This study classifies political autonomies in accordance with Thomas Benedikter's legalistic approach, which takes into account basic principles of constitutional law and democratic governance. There are other approaches that would be used in categorising political autonomies, including the objectivist approach and its pragmatist counterpart. For a detailed analysis of all these approaches, see Schulte, Felix. Conflict Regulation through Self-Rule: Success Factors of Territorial Autonomy Systems, Aland Islands Peace Institute, Mariehamn, 2015.

Several studies differentiate personal autonomy from its cultural counterpart. According to these studies, cultural autonomy is a community-based formulation, rendering it a communitarian (collectivistic) form of autonomy. Personal autonomy is an individual-centred formulation, making it an individualistic form of autonomy. This individualistic form seeks to protect individuals by granting them with the right to act upon their own discretion. This is not the case with the communitarian form, which tries to secure and develop collective identities. For more details, see Tkacik, Michael. "Characteristics of Forms of Autonomy", International Journal on Minority and Group Rights, vol. 15, no. 2, 2008, pp. 369-401; Abushov, Kavus. "Autonomy as a Possible Solution to Self-determination Disputes: Does It Really Work?", International Journal on Minority and Group Rights, vol. 22, no. 2, 2015, pp. 182-201; Weller, Marc. "Introduction", Asymmetric Autonomy and the Settlement of Ethnic Conflicts, edited by Marc Weller and Katherine Nobbs, University of Pennsylvania Press, Philadelphia, 2010, pp. 1-13.

Benedikter, p. 39.

The ultimate scope of personal/cultural autonomy encompasses all powers regarded necessary for the protection and advancement of ethnic, cultural, linguistic and/or religious identities. For more details, see Benedikter, p. 51.

This system permitted non-Muslim Ottoman groups to establish their own schools, courts and cultural sites. For more details, see Barkey, Karen / Gavrilis, George. "The Ottoman Millet System: Non-Territorial Autonomy and its Contemporary Legacy”, Ethnopolitics, vol. 15, no. 1, 2016, pp. 24-42.

Benedikter, p. 41.

Administrative autonomies may adopt secondary laws in several areas, e.g. local festivities, traditional customs, local/regional police and security, local/regional memorials and monuments, local/regional ethnonational symbols, etc. For more details, see Benedikter, p. 51. 
Territorial autonomy is the most common form of political autonomy. It provides territorially concentrated national minorities with the highest degree of self-rule. The carrier of territorial autonomy is a local (or regional) authority rather than an association of persons. Therefore, local (or regional) institutions established through this form of autonomy are independent from central state entities. Local or regional institutions exercising territorial autonomy are bestowed with both executive and legislative powers. This implies that they can adopt not only secondary laws (directives and regulations) but also primary laws (acts). The degree of self-rule provided via territorial autonomy exceeds that of personal/cultural and administrative autonomy. Not only matters concerning culture, language and education, but also economic and social policies are governed by local or regional authorities enjoying territorial autonomy. ${ }^{26}$

A significant number of European states, e.g. Belgium, Finland, Italy, Spain and the United Kingdom (UK), have adopted several constitutional arrangements since the 1950s that allow their national minorities to exercise territorial autonomy. ${ }^{27}$ These arrangements were strongly supported by European national minorities until the early 2000s. Since then some territorially concentrated national minorities have initiated strong secessionist movements aimed at transforming their autonomous regions into sovereign states. ${ }^{28}$ It is possible to find out many separatist movements across today's Europe that are led by self-ruling national minorities. ${ }^{29}$

The Scots provide a good example. Scotland began exercising legislative devolution (territorial autonomy) in 1998. The Scottish Parliament (Holyrood) was initially dominated by the unionist parties the Scottish Conservative Party, the Scottish Labour Party and the Scottish Liberal Democrats - who seek to protect Scotland's constitutional ties with the UK. ${ }^{30}$ Holyrood began changing its unionist character in 2007, when the pro-independence Scottish National Party (SNP) came into power via a minority government. ${ }^{31}$ The Parliament gained a strong separatist character in 2011, when the secessionist SNP and the Scottish Green Party gained 71 out of 129 seats. ${ }^{32}$ This resulted in a de jure Scottish independence

26 For a comprehensive analysis of territorial autonomy, see Légaré, André / Suksi, Markku. "Rethinking the Forms of Autonomy at the Dawn of the 21st Century", International Journal on Minority and Group Rights, vol. 15, no. 2, 2008, pp. 143-155; Olausson, Pär. Autonomy and Islands, a Global Study of the Factors that Determine Island Autonomy, Åbo Akademi University Press, Åbo, 2007.

27 For an extensive analysis of these arrangements, see Boulden, Jane / Kymlicka, Will. "Introduction", International Approaches to Governing Ethnic Diversity, edited by Jane Boulden and Will Kymlicka, Oxford University Press, New York, 2015, pp. 1-21; Suksi, Markku. Sub-state Governance through Territorial Autonomy: A Comparative Study in Constitutional Laws of Powers, Procedures and Institutions, SpringerVerlag, Heidelberg, 2011.

28 Secession refers to political disintegration and territorial dismemberment. It enables a territorial unit to establish its own sovereign state by withdrawing from an established and internationally recognised state. For a constitutional analysis of this concept, see Bartkus, Ona. The Dynamic of Secession, Cambridge University Press, Cambridge, 1999; Pavkovic, Aleksandar / Radan, Peter. Creating New States: Theory and Practice of Secession, Ashgate, Hampshire, 2007; Crawford, James. The Creation of States in International Law, $2^{\text {nd }}$ edition, Clarendon Press, Oxford, 2006; Buchanan, Allen. Secession: The Morality of Political Divorce from Fort Sumter to Lithuania and Quebec, Westview Press, Boulder, 1991.

29 Antunes, Sandrina / Loughlin, John. "The European Union, Subnational Mobilization and State Rescaling in Small Unitary States: A Comparative Analysis", Regional \& Federal Studies, vol. 30, no. 2, 2020, pp. 121136; Loughlin, John / Antunes, Sandrina. "State Rescaling and a 'Europe of the Regions' in Small Unitary States: A Damp Squib?”, Regional \& Federal Studies, vol. 30, no. 2, 2020, pp. 303-321. Connolly, Christopher. "Independence in Europe: Secession, Sovereignty, and the European Union", Duke Journal of Comparative and International Law, vol. 24, no. 1, 2013, pp. 51-52. Meer, Nasar. "Looking up in Scotland? Multinationalism, Multiculturalism and Political Elites", Ethnic and Racial Studies, vol. 38, no. 9, 2015, pp. 1478-1480.

32 Adam, Elisanda. "Self-Determination and the Use of Referendums: The Case of Scotland", International Journal of Politics, Culture, and Society, vol. 27, no. 1, 2014, pp. 47-48. 
referendum held on 18 September $2014 .{ }^{33}$ In the referendum, 55.3 per cent of Scots rejected Scottish independence on a turnout of 84.6 per cent. ${ }^{34}$ This did not settle the independence issue. ${ }^{35}$

In the 2016 Scottish parliamentary election, the pro-independence SNP and Scottish Greens obtained 69 out of 129 seats, and the Scottish Nationalists formed a minority government. ${ }^{36}$ Not long after, the UK held a referendum on its European Union (EU) membership, regarded as the 'Brexit Referendum', on 23 June 2016. In the referendum, British voters endorsed the UK to withdraw from the EU. 51.9 per cent of Britons voted to leave on a turnout of 72.2 per cent. ${ }^{37}$ There was no UK-wide consensus on the leave vote. While England and Wales backed the leave vote, Scotland, Northern Ireland and Gibraltar opted to remain. ${ }^{38}$ In Scotland, there was a consensus on the remain vote because all local authority areas saw remain majorities. ${ }^{39}$ The Brexit Referendum has resulted in another constitutional crisis for Scotland's future. ${ }^{40}$ The ruling SNP argues that "Scotland faces the prospect of being taken out of the EU against our will". ${ }^{41}$ This motivates the separatist Scottish Nationalists and Greens to hold another independence referendum after all Brexit terms become clear. ${ }^{42}$

In March 2017, the Scottish Parliament backed a Scottish government motion by a majority of 69 to 59, authorising Scotland's First Minister Nicola Sturgeon to make a formal request to the British government to hold a Scottish independence referendum. ${ }^{43}$ In December 2019, Sturgeon sent an official letter to British Prime Minister Boris Johnson that asked for the adoption of a settlement akin to the 2012 Edinburgh Agreement, which paved the way for the 2014 independence referendum. ${ }^{44}$ This request was rejected by Boris Johnson, who underlined in his official response to Sturgeon that the 2014 referendum

33 Dardanelli, Paolo / Mitchell, James. "An Independent Scotland? The Scottish National Party’s Bid for Independence and its Prospects", The International Spectator: Italian Journal of International Affairs, vol. 49, no. 3, 2014, pp. 88-91; Tierney, Stephen. "Legal Issues Surrounding the Referendum on Independence for Scotland", European Constitutional Law Review, vol. 9, no. 3, 2013, p. 360. Tierney, Stephen. "Reclaiming Politics: Popular Democracy in Britain after the Scottish Referendum", The Political Quarterly, vol. 86, no. 2, 2015, p. 226. Keating, Michael. "The Scottish Independence Referendum and After", Revista d'Estudis Autonòmics $i$ Federals, vol. 21, no. 1, 2015, pp. 73-74. Kolçak, Hakan. "Associate Statehood for Scotland as the Way to Stay in both the United Kingdom and the European Union: The Liechtenstein Example”, Romanian Journal of European Affairs, vol. 17, no. 1, 2017, p. 42.

Dodds, Anneliese. "Why People Voted to Leave and What to Do Now: A View from the Doorstep", The Political Quarterly, vol. 87, no. 3, 2016, p. 360. Ashcroft, Richard / Bevir, Mark. "Pluralism, National Identity and Citizenship: Britain after Brexit", The Political Quarterly, vol. 87, no. 3, 2016, pp. 355-356. Analysis of the Result", The Political Quarterly, vol. 87, no. 3, 2016, pp. 323-324. Hobolt, Sara. "The Brexit Vote: A Divided Nation, a Divided Continent", Journal of European Public Policy, vol. 23, no. 9, 2016, pp. 1260-1263.

Sturgeon, Nicola. "Nicola Sturgeon Responds to the Brexit Vote - Read her Speech in Full", Holyrood, (24.06.2016), https://www.holyrood.com/articles/inside-politics/\%20nicola-sturgeon-responds-brexit-voteread-her-speech-full, (Ac-cessed on: 10.09.2020).

Dickie, Mure. "SNP 'Resets' Plans for Second Scottish Independence Referendum”, Financial Times, (27.06.2017), https://www.ft.com/content/84e08f70-b852-3f95-9619-279fc5b93-683, (Accessed on: 24.09.2020). (28.03.2017), https://www.theguardian.com/politics/2017/mar/28/scottish-parliament-votes-for-secondindependence-referendum-ni-cola-sturgeon, (Accessed on: 25.09.2020). (19.12.2019), https://www.theguardian.com/politics/2019/dec/19/nicola-sturgeon-requests-independencereferendum-powers, (Ac-cessed on: 23.09.2020). 
was a "once in a generation vote". ${ }^{45}$ The rejection did not settle the Scottish independence issue. In January 2020, the Scottish Parliament adopted a government motion by a majority of 64 to 54 that expressed support for an independence referendum taking place on a date and in a manner determined by Holyrood. ${ }^{46}$ In the same month, the Parliament voted in favour of another motion ensuring that the EU flag continues to fly daily at the Holyrood building after the UK leaves the bloc. ${ }^{47}$

Since then the secessionist Scots have advocated holding an independence referendum. According to them, self-government rights set out in The Scotland Act 1998 - the backbone of the constitutional arrangement between Scotland and the UK - have enabled the Scots to exercise significant decision-making powers on several areas. ${ }^{48}$ However, they also underline that Scotland does not enjoy its sovereignty under the current constitutional settlement, undermining its capacity to fulfil Scottish demands. ${ }^{49}$ They believe that the people of Scotland should enjoy a democratic right to determine their own future. ${ }^{50}$ The Brexit Referendum indicates that Scotland's apparent choice is to stay in the EU. The constitutional organs of the Scottish devolved region are unable to satisfy this demand. Scotland is obliged to come out of the EU though this is not asked by the Scottish people. ${ }^{51}$ Therefore, the obligation is not consistent with the basic understanding of democracy that calls on the ruler to govern in accordance with demands of the ruled..$^{52}$ The separatist Scots consider a new independence referendum as a step that should be taken in advancing Scottish democracy..$^{53}$ According to them, backing Scottish independence in such a referendum would create a sovereign Scotland fulfilling all EU accession criteria in a short span of time. ${ }^{54}$ This would render

45 Learmonth, Andrew. "Boris Johnson Publishes Response to SNP's Section 30 Request", The National, (14.01.2020), https://www.thenational.scot/news/18158724.johnson-publishes-response-snps-section-30request, (Accessed on: 23.09.2020).

46 Macnab, Scott. "Scottish Parliament Backs Holding Indyref2 Vote This Year", The Scotsman, (29.01.2020), https://www.scotsman.com/news/scottish-news/scottish-parliament-backs-holding-indyref2-vote-year1395741, (Ac-cessed on: 27.08.2020).

47 Read, Carly. "Scottish Parliament to Keep Flying EU Flag after Brexit in Huge Snub to Referendum Result", The Express, (29.01.2020), https://www.express.co.uk/news/politics/123-5177/scottish-parliament-eu-flagbrexit-day-snp-nicola-sturgeon-latest, (Accessed on: 26.09.2020).

48 Sturgeon, Nicola. "We've Made a Real Difference: Nicola Sturgeon Reflects on 20 Years of Devolution", Yes, (01.07.2019), https://www.yes.scot/weve-made-a-real-difference-nicola-sturgeon-reflects-on-20-yearsof-devolution/, (Accessed on: 25.09.2020).

49 Davidson, Jenni. "Independence Referendum must be 'Legal and Legitimate', Nicola Sturgeon Emphasises in Brexit Day Speech", Holyrood, (31.01.2020), https://www.holyrood.com/news/view,independen-cereferendum-must-be-legal-and-legitimate-nicola-sturgeon-emphas 15048.htm, (Accessed on: 20.09.2020). Jefferson, Rodney / Morales, Alex. "Scotland's Leader Warns Johnson He 'can't Deny Democracy", Bloomberg, (10.02.2020), https://www.bloomberg.com/news/articles/2020-02-10/scotlands-leader-warnsboris-johnson-he-can-t-deny-democracy, (Accessed on: 23.09.2020).

51 Robertson, Angus. "A Whopping Majority Believes Scotland has Right to Decide over Indyref2”, The Scotsman, (28.01.2020), https://www.scotsman.com/news/politics/scottish-independence/whoppingmajority-believes-scotland-has-right-decide-over-indyref2-angus-robertson-1376832, $\quad$ (Accessed on: 25.09.2020).

52 Nutt, Kathleen. "Scotland could Rejoin EU Four-Five Years after Indy, Expert Says", The National, (22.05.2020), https://www.thenational.scot/news/18469817.scotland-rejoin-eu-four-five-years-indy-expertsays, (Accessed on: 18.09.2020).

53 Crowcroft, Orlando. "Scottish Independence Referendum: Sturgeon Says 'Democracy will Prevail' after New Vote Refused”, Euronews, (14.01.2020), https://www.euronews.com/2020/01/14/democracy-willprevail-says-sturgeon-after-johnson-refuses-second-scottish-referendum, (Accessed on: 27.08.2020).

54 Webster, Laura. "Unionists Furious as EU Boss Indicates Indy Scotland can Rejoin", The National, (20.05.2020), https://www.thenational.scot/news/18462298.unionists-furious-eu-boss-indicates-indy-scotland-can-rejoin, (Accessed on: 23.08.2020). 
the current devolved region a sovereign state within the EU, ultimately resulting in a scenario in harmony with the Scottish political choice. ${ }^{55}$

The Scots are not the only people who would like to transform their devolved region into a sovereign state. There is an active movement in Wales, a devolved region of the UK, that asks for the establishment of an independent Wales. This political movement is led by the Party of Wales (Plaid Cymru), which has been an important actor in Welsh constitutional politics since the establishment of the Welsh devolved region in $1998 .^{56}$

A dominant secessionist movement is growing in Catalonia, a self-ruling region of the Spanish Kingdom. The autonomous community is ruled by the separatists who would like to establish a sovereign Catalan republic. This Catalan demand is rejected by the Spanish government, which does not authorise its Catalan counterpart to hold a de jure independence referendum. ${ }^{57}$ There are other separatist organisations, political parties and alliances active in some Spanish autonomous communities, e.g. the Balearic Islands, the Basque Country, the Canary Islands and Galicia. ${ }^{58}$

$55 \quad$ For a detailed analysis of how Scotland would become an EU member state after its independence, see Bullock, Steve. "What Representation Would an Independent Scotland Have in the EU?", An Independent Scotland in the EU: Issues for Accession, edited by Kirsty Hughes, Scottish Centre on European Relations Publication Office, Edinburgh, 2020, pp. 20-22; Lock, Tobias. "Negotiating EU Accession: Lessons for an Independent Scotland", An Independent Scotland in the EU: Issues for Accession, edited by Kirsty Hughes, Scottish Centre on European Relations Publication Office, Edinburgh, 2020, pp. 9-12; McEwen, Nicola. "Devolution and Alignment with EU Laws", An Independent Scotland in the EU: Issues for Accession, edited by Kirsty Hughes, Scottish Centre on European Relations Publication Office, Edinburgh, 2020, pp. 13-16; Zuleeg, Fabian. "Transition from the UK and to the EU", An Independent Scotland in the EU: Issues for Accession, edited by Kirsty Hughes, Scottish Centre on European Relations Publication Office, Edinburgh, 2020, pp. 17-19.

For a comprehensive analysis of the Welsh case, see Kolçak, Hakan. "Unionist Wales: A Comprehensive Analysis of the Welsh Devolved Region via Constitutional and Legal Perspectives", Public Administrative Studies, edited by Sefer Y1lmaz, Akademisyen Publishing House, Ankara, 2020, pp. 1-21; Mullen, Tom. "Brexit and the Territorial Governance of the United Kingdom", Contemporary Social Science, vol. 14, no. 2, 2019, pp. 276-293.

57 For all significant details of the Catalan case, see Kolçak, Hakan. "From Unionism to Secessionism: A Comprehensive Analysis of Contemporary Catalan Politics", Journal of Society and Politics, vol. 12, no. 1, 2017, pp. 25-52; Andreu, Josep. "Constitution and Referendum on Secession in Catalonia", Claims for Secession and Federalism: A Comparative Study with a Special Focus on Spain, edited by Alberto LópezBasaguren and Leire Escajedo San-Epifanio, Springer, New York, 2019, pp. 405-422; Castillo, Antonio. "State Integration and Disintegration within the European Union: Regarding the Purported Secession of Catalonia and its Hypothetical Membership of the EU", Claims for Secession and Federalism: A Comparative Study with a Special Focus on Spain, edited by Alberto López-Basaguren and Leire Escajedo San-Epifanio, Springer, New York, 2019, pp. 563-574; Swan, Brown / Cetra, Daniel. "Why Stay Together? State Nationalism and Justifications for State Unity in Spain and the UK", Nationalism and Ethnic Politics, vol. 26, no. 1, 2020, pp. 46-65; Wagner, Andrea / Marin, Jianna / Kroqi, Dorian. "The Catalan Struggle for Independence and the Role of the European Union”, Regional Science Policy \& Practice, vol. 11, no. 5, 2019, pp. 787-803.

For more details on the secessionist movements in Spain, see Corral, Benito / Freijedo, Francisco. "Constitutionalizing Secession in Order to Harmonize Constitutionality and Democracy in Territorial Decentralized States Like Spain”, Claims for Secession and Federalism: A Comparative Study with a Special Focus on Spain, edited by Alberto López-Basaguren and Leire Escajedo San-Epifanio, Springer, New York, 2019, pp. 265-285; Gray, Caroline. Territorial Politics and the Party System in Spain: Continuity and Change since the Financial Crisis, Routledge, London, 2020; Kolçak, Hakan. "Ongoing Unionism: A Comprehensive Analysis of Galicia via Constitutional and Legal Perspectives", Selected Studies on Social Science, edited by Özlem Kaya, Iksad Publications, Ankara, 2020, pp. 3-42; Mas, Joaquin. "Secession and Federalism: The Spanish Case", Claims for Secession and Federalism: A Comparative Study with a Special Focus on Spain, edited by Alberto López-Basaguren and Leire Escajedo San-Epifanio, Springer, New York, 2019, pp. 389404. 
It is possible to find out similar political movements in other European countries. A strong separatist movement is effective in the Flemish Region of the Belgian Kingdom. The movement is led by the New Flemish Alliance (Nieuw-Vlaamse Alliantie), which is a mainstream political party in Flemish constitutional politics. A less powerful movement is developed in Wallonia, which is a federal component of Belgium. ${ }^{59}$ The Bavaria Party (Bayernpartei) develops a political movement aimed at transforming the Free State of Bavaria - a federal constituent of Germany - into a sovereign state. ${ }^{60}$ Similar developments exist in France and Finland. The For Corsica Coalition (Pè a Corsica) is a political alliance between the autonomists (Femu a Corsica) and separatists (Corsica Libera). The Coalition intends to turn Corsica - a French island in the Mediterranean Sea - into a sovereign state. ${ }^{61}$ The Future of Aland (Alands Framtid) seeks to achieve a similar goal transforming the Aland Islands - a self-governing Finnish archipelago - into a sovereign state. ${ }^{62}$ Similar parties are found in Sardinia and Sicily, which are designed as autonomous regions by the Italian Constitution. ${ }^{63}$ It is worth noting that the movements in Belgium, France, Finland, Germany and Italy are not as powerful as those developed in the UK (Scotland) and Spain (Catalonia). But nevertheless, these movements are still undergoing their gradual enlargement operations. It is always possible for them to become mass-based political movements as strong as their Scottish and Catalan counterparts.

All in all, there are many secessionist movements across Europe that are led by territorially concentrated national minorities. These minorities are not satisfied with self-government rights allowing them to exercise territorial autonomy within their home states. Rather, they would like to turn their selfruling regions into sovereign states. This demand is considered by secessionist national minorities as a democratic requirement. Sovereign home states that seek to protect their territorial integrity have been unwilling to fulfil this minority demand so far. It is worth noting, however, that the number of separatist national minorities is increasing day by day. This circumstance would eventually stimulate sovereign states to find out constitutional resolutions to secession-related minority issues. Confederal arrangements would play a significant role in formulating such resolutions. Let us first comprehend confederalism in the next section.

\section{Understanding Confederal Governance}

Various scholars define the constitutional notion of confederation differently though there are certain common features in all definitions, e.g. the existence of founding treaties, extensive self-rule, limited shared rule, sovereign regional governments and weak central governments. Daniel Elazar defines confederation as " a situation in which two or more polities come together to establish a limited-purpose general government that functions through the constituent states, which retain their position as the primary political

$59 \quad$ For a detailed analysis of the separatist movements in Belgium, see Mastromarino, Anna. "Secessionist Claims in a Federal System: The Belgian Case", Claims for Secession and Federalism: A Comparative Study with a Special Focus on Spain, edited by Alberto López-Basaguren and Leire Escajedo San-Epifanio, Springer, New York, 2019, pp. 221-232. of the European Union from the Perspective of Intra-Community Secessionist Movements", European Integration Realities and Perspectives, vol. 14, no. 1, 2019, pp. 313-318. For more details on the Corsican case, see Boylan, Brandon / Turkina, Ekaterina. "Calling on Europe? Secessionist Political Parties and Their Communications to the European Union", Journal of Common Market Studies, vol. 57, no. 6, 2019, pp. 1310-1332. of Ethnic Minority Political Strategy in Europe", Nations and Nationalism, vol. 25, no. 1, 2019, pp. 229-297.

63 For more details on the Italian cases, see Keating, Michael. "Is a Theory of Self-Determination Possible?", Ethnopolitics, vol. 18, no. 3, 2019, pp. 315-323. 
communities, retaining ultimate sovereignty within the overall polity" ${ }^{64}$ Similarly, Valery Perry argues that "sovereignty is held by the lower-level [regional] units of government" while its central counterpart "has very weak competencies, perhaps limited to matters of joint foreign policy and defence" ${ }^{65}$ Ivo Ducháček underlines the strong regional nature of confederal governance by noting that "confederal components cannot and do not accept a subordination to a numerical majority of other sovereignties except in marginal matters". ${ }^{66}$

Ronald Watts recognises confederation as "a species of federal system in which the institutions of shared rule are dependent on the constituent governments, being composed of delegates from the constituent governments and therefore having only an indirect electoral and fiscal base". ${ }^{67}$ In a similar vein, Michael Stevens underpins the indirect electoral base of confederation by declaring that "the scope of political integration is limited to the interactions of the constituent-states while the individual citizen is excluded from direct participation". ${ }^{8}$ Frederick Lister sees confederation "as an undertaking by a group of states to create a special order among themselves that is superior to that of the international order (or disorder) to which all states belong". ${ }^{69}$ Stefan Wolff considers it as "a voluntary association of sovereign member states", providing them with "extensive self-rule without institutionalised shared rule" ${ }^{70}$ Finally, Alfred Stepan regards confederation as "an agreement between states", authorising them to "make a unilateral decision not to participate in a collective foreign policy endeavour, unless such a decision violates the specific treaty creating the confederation". ${ }^{71}$

As a type of governance, confederalism unites states without depriving them of their statehood. The main purpose for unification is to form "viable federal-type unions". ${ }^{72}$ Any practice of confederal governance is based upon a written basic law (treaty or constitution) that is legally binding on all confederal allies. The central division of confederal government is bestowed by the basic law only with a minimalist mandate, e.g. military integration or coordination, internal commerce and external trade, common markets, etc. Confederal governance is indeed "a means of unifying diverse peoples". ${ }^{73}$ It rests upon and operates

64 Elazar, Daniel. Federalism: An Overview, Human Sciences Research Council Publishers, Pretoria, 1995, p. 6.

Perry, Valery. "Constitutional Reform in Bosnia and Herzegovina: Does the Road to Confederation Go through the EU?", International Peacekeeping, vol. 22, no. 5, 2015, p. 497. Ducháček, Ivo. "Consociational Cradle of Federalism", Publius: The Journal of Federalism, vol. 15, no. 2, 1985, p. 46.

Watts, Ronald. "Federalism, Federal Political Systems, and Federations", Annual Review of Political Science, vol. 1, no. 1, 1998, p. 121. Stevens, Michael. "Asymmetrical Federalism: The Federal Principle and the Survival of the Small Republic", Publius: The Journal of Federalism, vol. 7, no. 4, 1977, p. 182.

Lister, Frederick. The European Union, the United Nations, and the Revival of Confederal Governance, Greenwood Press, London, 1996, p. 33.

70 Wolff, Stefan. "Post-Conflict State Building: The Debate on Institutional Choice", Third World Quarterly, vol. 32, no. 10, 2011, p. 1785; Wolff, Stefan. "Conflict Management in Divided Societies: The Many Uses of Territorial Self-Governance", International Journal on Minority and Group Rights, vol. 20, no. 1, 2013, p. 32.

Stepan, Alfred. "A Revised Theory of Federacy and a Case Study of Civil War Termination in Aceh, Indonesia", Power Sharing in Deeply Divided Places, edited by Joanne McEvoy and Brendan O'Leary, University of Pennsylvania Press, Philadelphia, 2013, pp. 238-239. Lister, p. 33.

73 Wirt, Frederick. "The Tenacity of Confederacy: Local Service Agreements in the Family of Governments", Publius: The Journal of Federalism, vol. 12, no. 4, 1982, p. 111. 
through confederal allies or member states that exercise significant sovereign powers. ${ }^{74}$ This circumstance renders confederations voluntary associations of sovereign states or leagues of independent polities. ${ }^{75}$

Member states in a confederation are considered as the regional governments of that confederation. They are authorised to exercise legislative, executive and judicial powers. This authorisation is provided by supreme laws (treaties) rather than the central administration of the confederation. This means that the regional level of confederal governance is not subordinated to its central counterpart. As the regional governments of the confederation, member states enjoy their sovereign statehood. They are entitled to exercise treaty-making powers, rendering them subjects of international law. ${ }^{76}$ The sovereign nature of the states is recognised by the UN, enabling them to enjoy equal status with independent states at the international political level. ${ }^{77}$ Their sovereignty is acknowledged in the constitutional framework of the confederation. They are bestowed with the authority to construct and develop their own domestic public and private law spheres without any central interferences of the confederation. The sovereign status of member states is protected by a treaty-based protection mechanism. This means that the sovereignty of member states is recognised by a bilateral or multilateral treaty establishing the confederation concerned. ${ }^{78}$

The confederal form of governance (confederalism) attracted a negative evaluation in The Federalist, a collection of eighty-five essays that laid the foundation for the Constitution of the United States of America (USA) ${ }^{79}$ Confederal governance has been in a stage of revival particularly since the second half of the twentieth century when various international economic unions and transnational associations were

74 Ducháček, Ivo. "Consociations of Fatherlands: The Revival of Confederal Principles and Practices", Publius: The Journal of Federalism, vol. 12, no. 4, 1982, p. 129.

75 Elazar, Daniel. "From Statism to Federalism: A Paradigm Shift", Publius: The Journal of Federalism, vol. 25 , no. 2,1995 , p. 5 .

76 Treaty-making powers allow sovereign states or self-ruling regions to negotiate, sign, ratify and conclude treaties. There are two more treaty-related powers, namely treaty-affecting and treaty-implementing. Treatyaffecting powers permit self-governing regions to participate in treaty-making processes. Treatyimplementing powers enable autonomous regions to exclude treaty provisions (fully or partly) from entering into force in regional jurisdictions. For more details, see Silverström, Sören. "The Competence of Autonomous Entities in the International Arena: With Special Reference to the Aland Islands in the European Union", International Journal on Minority and Group Rights, vol. 15, no. 2, 2008, pp. 259-271.

77 The international political level is a dimension where only intergovernmental political organisations, e.g. the UN, the EU or the Nordic Council, are involved. Other international organisations, e.g. the Union of European Football Association and the International Federation of Association Football, are not included in the scope of this political dimension. For more details, see Ichijo, Atsuko. "Sovereignty and Nationalism in the Twentyfirst Century: The Scottish Case”, Ethnopolitics, vol. 8, no. 2, 2009, pp. 155-172; MacCormick, Neil. Questioning Sovereignty: Law, State and Practical Reason, Oxford University Press, Oxford, 1999.

78 The treaty-based protection mechanism adopts its legal provisions via multilateral treaties. It provides a sort of international protection for constitutional arrangements. It is possible to establish different protection systems, including ordinary legal protection systems, conventionally entrenched protection systems and constitutionally entrenched protection systems. These systems are shaped via various principles and rules on mutual consultation, judicial review, supermajority change and mutual assent. For more details, see Kolçak, Hakan. "Multinational Federalism, Accommodation Policies and State Models: The Management of National Minorities", 2. International 19 May Innovative Scientific Approaches Congress Proceedings, 27-29 December 2019, Samsun, edited by Iasha Bekadze and Samira Khadhraoui Ontunç, Farabi Publications, Gaziantep, 2019, pp. 1304-1333; Rezvani, David. Surpassing the Sovereign State: The Wealth, Self-rule and Security Advantages of Partially Independent Territories, Oxford University Press, Oxford, 2014; Rezvani, David. "Partial Independence Beats Full Independence", Territory, Politics, Governance, vol. 4, no. 3, 2015, pp. 269-296; Suksi, Markku. "Explaining the Robustness and Longevity of the Aland Example in Comparison with Other Autonomy Solutions", International Journal on Minority and Group Rights, vol. 20, no. 1, 2013, pp. 51-66.

The essays were written by Alexander Hamilton, John Jay and James Madison. For more details on them, see Elazar, Daniel. "Confederation and Federal Liberty", Publius: The Journal of Federalism, vol. 12, no. 4, 1982, pp. 1-14 
constructed on confederal bases. ${ }^{80}$ Danial Elazar underscores this rise of confederalism by saying that "with the emergence of permanent multinational communities, of which the European Community [EU] is the prime example, we are now witnessing a revival of confederal arrangements" ${ }^{81} \mathrm{He}$ considers permanent multinational communities, e.g. the EU, the Caribbean Community and the Association of South East Asian Nations, as confederal unions of specific functions. According to him, these communities have enabled their member states to remain independent while creating an energetic form of transnational governance in certain areas. ${ }^{82}$

\section{Confederal Arrangements: The Elements of Resolution}

It is a common goal of almost all secessionist national minorities to transform their autonomous regions into sovereign states. As a basic political and constitutional term, sovereignty has two essential conceptions: an empirical conception and its juridical counterpart. The empirical conception of sovereignty refers to "the location of supreme power within a particular territorial unit, necessarily came from within and therefore did not require the recognition of other States or princes" ${ }^{83}$ Under the empirical conception, a community is required to satisfy the following four conditions for sovereign statehood: (a) a defined territory; (b) a permanent population; (c) effective authority over the territory and population; and (d) independence from external control. ${ }^{84}$ The juridical conception of sovereignty refers to a legal status in international law which is bestowed upon a state who has fulfilled all the four requirements of the empirical conception and whose sovereign statehood has been recognised by the international community, namely the UN..$^{85}$

The modern meaning of sovereignty includes both empirical and juridical conceptions. To clarify, there are many cases in which states obviously meet all requirements of the empirical conception, but their sovereign statehood is questioned as they have not been recognised by the international community. A significant number of secessionist national minorities, such as the Abkhazians and Transnistrians, successfully challenged their home states - Georgia and Moldova, respectively. They constructed their own civil administrations in their territories to maintain order and provide main social services to their people. Despite the fact that these groups are very likely to have fulfilled the traditional empirical conditions for sovereign statehood, they have been regarded as quasi or sham, but not sovereign, states due to the lack of their recognition by the international community. In the modern world, a state can gain its sovereignty after its recognition by the international community, thereby providing the state with both an opportunity to become a subject of international law and an equal status with independent states at the international political level. ${ }^{86}$ Hence, sovereignty is the essential characteristic of statehood that authorises a state (1) to rule its internal and foreign affairs without any external interferences; (2) to locate the supreme legitimate power within its own jurisdiction (e.g. the king, the parliament, etc.); (3) to enjoy an equal status with independent states at the international political level; and (4) to become a subject of international law. The first two elements of this definition are reflections of the empirical conception. The first element empowers the state to establish and develop its own public and private law spheres. The second element enables the state to officially recognise the ultimate sovereign power within its domestic jurisdiction. The last two

$80 \quad$ Elazar, Daniel. "Introduction: Using Federalism Today”, International Political Science Review, vol. 17, no. 4, 1996, p. 349.

81 Elazar, Daniel. Exploring Federalism, University of Alabama Press, Tuscaloosa, 1987, pp. 50-51.

82 Elazar, Daniel. "Contrasting Unitary and Federal Systems", International Political Science Review, vol. 18, no. 3, 1997, pp. 237-251.

83 Crawford, James. "The Criteria for Statehood in International Law", British Yearbook of International Law, vol. 48, no. 1, 1976, p. 96.

Bartkus, p. 219.

Bartkus, pp. 220-222.

Ichijo, pp. 159-170. 
elements are indications of the juridical conception. The third element allows for the recognition of the state not only by independent states but also by the UN. The last element permits the state to exercise treatyrelated powers that are key tools to become a subject of international law.

Admission to UN membership is regarded as the ultimate task that an independent state should fulfil for international recognition. ${ }^{87}$ According to the UN, not only is outright independence a form of full selfgovernment, but free association is also another type that enables a state to enjoy full self-government. ${ }^{88}$ This approach permits various freely-associated states to become UN member states. Associate states are established via confederal arrangements. These arrangements enable a sovereign state to devolve some of its powers, such as those in the fields of diplomacy and defence, to another sovereign state without endangering its sovereignty status in international law. ${ }^{89}$ The devolution process is mostly completed by means of bilateral or multilateral treaties that would be terminated by state parties without receiving permission from each other..$^{90}$ In the presence of such treaties, associate states have its own constitutions, authorising them to construct, secure and advance their domestic public and private law spheres. ${ }^{91}$

There are many freely associated sovereign states across the globe, including the Principality of Monaco (France), the Republic of San Marino (Italy), the Principality of Liechtenstein (Switzerland), the Principality of Andorra (Spain-France), the Republic of the Marshall Islands (USA), the Republic of Palau (USA) and the Federal States of Micronesia (USA). ${ }^{92}$ All these associate states are the products of confederal arrangements shaped via bilateral or multilateral treaties. For instance, Liechtenstein and Switzerland established the roots of their confederal relationship via a customs union treaty that entered into force on 1 January 1924. The relationship was further developed and consolidated via subsequent treaties, e.g. the Patent Protection Treaty of 1979 and the Currency Treaty of 1980. All treaties have eventually institutionalised the confederal relationship and rendered Liechtenstein a sovereign UN member state in free association with Switzerland. ${ }^{93}$

Similar confederal arrangements would be adopted in order to resolve secession-specific minority issues. Secession is not the only way of establishing sovereign states. Confederal arrangements are potential alternatives that would lead to the establishment of sovereign associate states. This implies that separatist national minorities would achieve their main goal via confederal settlements. Some may argue that confederal arrangements adopted between national minorities and their home states lead to the certain break-up of the established constitutional systems as happened in Czechoslovakia, the Soviet Union and Yugoslavia. It is possible to support this argument from a theoretical point of view. The institutional structures of the aforementioned three states were built on some confederal features. ${ }^{94}$ However, it is unlikely for us to back the argument from a practical perspective. Czechoslovakia, the Soviet Union and Yugoslavia implemented sham or pseudo confederal arrangements. They were not democratic confederal

\footnotetext{
$87 \quad$ Kolçak, 2019, p. 1311.

88 Principles which Should Guide Members in Determining whether or not an Obligation Exists to Transmit to the Information Called for under Article 73(e) of the Charter, 15 December 1960, UN General Assembly Resolution 1541/15, principle VII.

89 Mautner, Menachem. "West Bank and Gaza: The Case for Associate Statehood", Yale Journal of International Law, vol. 6, no. 2, 1981, pp. 297-360

Benedikter, p. 294.

Lapidoth, pp. 50-58.

Dumieński, Zbigniew. Microstates as Modern Protected States: Towards a New Definition of MicroStatehood, Institute of International Affairs, Auckland, 2014, p. 25.

For an extensive constitutional analysis of the confederal relationship between Liechtenstein and Switzerland, see Kolçak, “Associate Statehood...”, pp. 48-51.

94 Antonić, Slobodan. “Could a Confederation Have Saved Yugoslavia?”, Nationalities Papers: The Journal of Nationalism and Ethnicity, vol. 25, no. 3, 1997, pp. 469-472.
} 
states, but tightly centralised Marxist dictatorships. ${ }^{95}$ The regional governments of the dictatorships were subject to the whims of the extremely centralised Communist Party. ${ }^{96}$

Some would assert that confederal arrangements resolve secession-related minority issues temporarily because separatist national minorities are loyal to their regional states rather than confederal relationships with their host states. It is worth noting that regional loyalties would turn into confederal allegiance constructed upon shared common interests and mutual trust, leading to the foundation of powerful federations or unitary states. This is what happened with all four of the prototypal confederal states (American, Dutch, German and Swiss Confederations). These states "evolved in ways that made it possible for them to become highly stable federal or unitary states". ${ }^{97}$ They were collective security confederations once established. This implies that they were founded since their member states had faced a long-term threat to their existence or independence. The American Confederation was established to fend off the British attacks; the Dutch Confederation against the Spanish Habsburgs and the French; the Swiss Confederation in response to the Austrian Habsburgs and other invaders; and finally the Germanic Confederation to keep out the post-Napoleonic French. These loose political unions then initiated a process of social integration which, in each instance, ultimately resulted in "the emergence of a new people living in the closer union of a federal or of a centralised 'unitary' state". 98

In the second half of the sixteenth century, the western provinces forming the Dutch Republic (Holland, Utrecht and Zeeland) had different ethnic, cultural and religious characteristics from those of the eastern provinces (Friesland, Gelderland, Groningen and Overyssel). The only common feature between the two regions was a dislike of Philip II, who was the Spanish Habsburg overlord. In the late sixteenth century, the eastern provinces were forcibly incorporated in the Dutch Republic because Holland and Zeeland required a territorial barrier to safeguard them from overland attacks. Not long after this incorporation, the antagonism of the easterners disappeared since the Republic thrived. Their provinces were acknowledged as full members of the States-General, which was the legislative body of the Republic. This circumstance set the eastern provinces above their neighbours, including the Flemings of Brabant and Flanders, who had various cultural, ethnic and linguistic characteristics akin to those of the Hollanders and Zeelanders. The inhabitants of the eastern provinces became loyal Dutchmen with the disappearance of this hostility, leading to the creation of the current unitary Netherlands. ${ }^{99}$

Similar to the early period of the Dutch Confederation, there were various ethno-cultural differences among the Bavarians, Saxons and Rhinelanders in post-Napoleonic Germany. With the establishment of the Germanic Confederation (1815-1866), a common German identity grew that helped Bismarck succeed in unifying German states. ${ }^{100}$ Following the unification, Germany established and developed a federal trust with the principle of Bundestreue, which is still given life and concretisation. The principle is enshrined by the German Federal Constitutional Court (Bundesverfassungsgericht). ${ }^{101}$ Bundestreue, rendering federalism an overriding constitutional norm in the present Federal Republic of Germany, is now " $a$ founding principle of post-totalitarian German political culture, based on constitutional patriotism, a substitute to the former "national patriotism". ${ }^{102}$ The German concept of constitutional patriotism is

\footnotetext{
95 McGarry, John. "Asymmetry in Federations, Federacies and Unitary States", Ethnopolitics, vol. 6, no. 1, 2007, p. 110.

96 Kymlicka, Will / Raviot, Jean-Robert / Lee, Steve. "Living Together: International Aspects of Federal Systems”, Canadian Foreign Policy Journal, vol. 5, no. 1, 1997, p. 18.

Lister, p. 23.

Lister, p. 12.

Lister, pp. 12-13.

Lister, p. 13.

Kymlicka / Raviot / Lee, p. 32.

Kymlicka / Raviot / Lee, pp. 32-33.
} 
inclined to replace the notion of nation. Having respect for the German Constitution "is supposed to be a substitute for the sense of belonging to the nation". ${ }^{103}$ With the existence of this unwritten constitutional principle, all inhabitants of Germany's federal components (Länder), except for few Bavarians, are loyal to their republican federal state.

The early histories of the American and Swiss Confederations were similar to their Dutch and German counterparts. The city-state and mountain cantons of the Swiss Confederation were initially disparate entities whose peoples had only one common feature, namely the need for security against the Austrian Habsburgs and other external enemies. Similarly, in the early period of the American Confederation, there were many crosscurrents of antagonism among several states, such as the hostility between the Virginians and New Englanders. The peoples of the thirteen American states had different social and religious characteristics. Each state acquired its unique identity during the long British colonial period. After establishing their collective security confederations, the principal regional loyalties of the Swiss cantons and American states turned into confederal allegiance, enabling the USA and Switzerland to establish their current federal states. ${ }^{104}$

In each of the above prototypal confederal cases, a loose political union was founded first. Then, popular communities were shaped with the transformation of regional loyalties to confederal allegiance. The Benelux Union, which is a confederation made up of the Low Countries (Belgium, Luxembourg and the Netherlands), has pursued a similar transformation process since its establishment. ${ }^{105}$ The Low Countries are the precursors of European integration. ${ }^{106}$ They have shared close geographic and sociocultural ties for hundreds of years, albeit their various distinct linguistic and political characteristics. ${ }^{107}$ The Benelux Union is the ultimate product of a three-step evolution process: (i) the establishment of a customs union; (ii) the construction of an economic union as the successor of the customs union; and (iii) the foundation of a confederation as the successor of the economic union.

The Benelux Union had its historic roots in the integrative attempt between the Low Countries and the Nordic Countries in the 1930s. At that time, these countries tried to make a tariff alliance, known as the Oslo Alliance. This initial attempt was unsuccessful due to the opposition of larger countries. Nevertheless, it enabled the Low Countries to realise the significance of institutionalised collective action, encouraging them to initiate a new integration process during the Second World War. ${ }^{108}$ The governments of the Low Countries signed a monetary agreement in London on 21 October 1943. This agreement was adopted by their national parliaments in 1946. The agreement fixed exchange rates between the Dutch guilder and the

\footnotetext{
$103 \quad$ Kymlicka / Raviot / Lee, p. 33.

104 For more details on the American and Swiss cases, see Lister, pp. 11-33.

105 Bursens, Peter / Crum, Ben. "The Benelux Countries: How Politicization Upset a Pro-Integration Coalition", National Politics and European Integration: From the Constitution to the Lisbon Treaty, edited by Maurizio Carbone, Edward Edgar Publishing, Cheltenham, 2010, pp. 144-148. Casier, Tom. "The Bilateral Relations of the Benelux Countries with Russia: Between Rhetorical EU Engagement and Competitive Business Interests", Journal of Contemporary European Studies, vol. 19, no. 2, 2011, pp. 237-239; Maes, Ivo / Verdun, Amy. "Small States and the Creation of EMU: Belgium and the Netherlands, Pace-setters and Gate-keepers", Journal of Common Market Studies, vol. 43, no. 2, 2005, pp. 327-330.

107 Meijer, Erik. "The Radical Left in Benelux”, Socialism and Democracy, vol. 29, no. 3, 2015, pp. 71-73.

108 Jones, Erik. The Benelux Countries: Identity and Self-Interest, John Hopkins Bologna Centre, Bologno, 2003, pp. 3-9.
} 
Belgian franc. ${ }^{109}$ The monetary agreement was followed by a customs union settlement that entered into force on 1 January 1948. This settlement created one tariffs union among the Low Countries. ${ }^{110}$

In the late 1940s, the Low Countries embarked on a new process to create an economic union that would move beyond its customs counterpart. They signed a preliminary Benelux union treaty on 15 October 1949. This was followed by the treaty of 18 February 1950. The treaty sought to unify excise duties and simplify collections at the borders. A new convention on customs and excise was signed on 5 September 1952. At that time, another convention on mutual assistance to recover fiscal debts was signed. The Protocol on Foreign Trade Policy, including several import and export regulations, was signed on 9 December 1953. The next three steps were taken with the Agreement on the Liberalisation of Capital Movements (8 July 1954), the Treaty for the Free Movement of Labour (7 June 1956) and the Protocol on Government Procurement (6 July 1956). All these attempts eventually empowered the Low Countries to sign the Treaty Establishing the Benelux Economic Union on 3 February 1958. The Treaty became effective on 1 November 1960, rendering the former customs union an economic union through establishing a single market. ${ }^{11}$ The Treaty brought about total economic integration by providing free movement of capital, goods, persons and services among all Benelux regions. It allowed the Low Countries to not only coordinate economic, financial and social policies but also pursue a common foreign trade policy. ${ }^{112}$

In the following years, a more integrationist and collaborative Benelux programme was adopted in light of the Treaty of $1958 .{ }^{113}$ This programme (i) standardised postal and transport rates; (ii) coordinated welfare policies; (iii) annulled exit controls at the internal borders of the Low Countries; ${ }^{114}$ and (iv) adopted common policies on infrastructural issues (e.g. communication, sewage handling and disposal, etc.) and environmental matters (such as air, water and noise pollution). ${ }^{115}$

The Treaty of 1958 was limited to a period of fifty years, meaning that it would expire on 31 October 2010. This circumstance led the Benelux Countries enter a new period re-establishing the confederation. On 17 June 2008, the governments of the Low Countries decided to deepen, strengthen and extend their cooperation by introducing a new legal framework - the Treaty Revising the Treaty Establishing the Benelux Economic Union - rather than prolonging the existing treaty. The 2008 Treaty of the Benelux Union came into effect on 1 January $2012 .{ }^{116}$ The 2008 Treaty defines the existing confederation as the which was signed on 25 July 1921 with the aims of equalising customs tariffs and moving towards a single balance of payments. Studies, Leuven, 2008, pp. 8-20; Belkahla, Mehdi. Benelux Court of Justice, Max Planck Institute, Luxembourg, 2017, pp. 3-4. Benelux Structural Outline", European Planning Studies, vol. 16, no. 6, 2008, pp. 853-859; Zonneveld, Wil / Faludi, Andreas. "Vanishing Borders: The Second Benelux Structural Outline", Built Environment, vol. 23, no. 1, 1997, pp. 4-6. 19; Witlox, Frank / Dullaert, Wout / Jourquin, Bart. "Fostering Transport and Logistics Research in the Benelux Countries", Transportation Planning and Technology, vol. 30, no. 4, 2007, p. 325. It is worth noting that the Treaty was amended on 16 March 1971, 26 January 1976 and 16 February 1990. This enabled not only the nationals of the Benelux Countries but also those of other states to move freely across all Benelux frontiers. European Law Journal, vol. 10, no. 2, 2004, pp. 153-161.

116 The Treaty Establishing the Benelux Union, 3 February 1958, 381 UNTS 5471 (as revised by the Treaty Revising the Treaty Establishing the Benelux Economic Union, 17 June 2008 (hereinafter the 2008 Treaty of the Benelux Union). 
Benelux Union. ${ }^{117}$ It gives the Union an international legal personality for the goal of granting privileges and immunities. ${ }^{118}$ The Treaty is a framework law that is in force for an unlimited period. ${ }^{119}$ According to the Treaty, the Low Countries "establish a Benelux Union in order to defend their common interests and to promote the well-being of their populations". ${ }^{120}$ The Treaty reads that "[t]he purpose of the Benelux Union is to deepen and expand the cooperation between the High Contracting Parties [...] and strengthen and improve cross-border cooperation at every level". ${ }^{21}$ The Treaty lists the main objectives of the confederation as follows: (i) the maintenance and development of the Benelux internal market; (ii) the promotion of sustainable development and the protection of environment; and (iii) the establishment of collaborative organs in the fields of justice and home affairs. ${ }^{122}$ The Low Countries and the central institutions of the Benelux Union - the Committee of Ministers, the Benelux Council, the Benelux Interparliamentary Advisory Council, the Benelux Court of Justice and the Benelux General Secretariat - not only seek to achieve these objectives, they also intend to adopt multilateral treaties in the areas of police and defence that would create a fully integrated union, perhaps a Benelux federation. ${ }^{123}$

It is possible for associate states and their host states to undergo similar integrationist operations. For example, Liechtenstein and Switzerland formed their loose political union via a customs union treaty became effective in 1923. They created a monetary union in the following year. The confederal relationship was further developed and intensified via bilateral treaties in the subsequent years, resulting in the foundation of several common mechanisms, e.g. a common consular and diplomatic representation system, a common defence system, a common patent protection system, a common alien office and a common value-added tax system. All these common mechanisms and their forthcoming counterparts would turn the associate state of Liechtenstein into a federal component of Switzerland in the long run. ${ }^{124}$

\section{CONCLUSION}

There are numerous separatist movements across Europe that are organised by territorially concentrated national minorities, e.g. the Catalans and the Scots. These minorities would like to turn their autonomous regions into sovereign states. European states are unwilling to fulfil this minority demand. It

117 The 2008 Treaty of the Benelux Union, art. 1.

118 The 2008 Treaty of the Benelux Union, art. 28.

119 According to Article 39/2 of the Treaty, the Benelux Countries would "denounce the Treaty with a period of three years commencing on the day of receipt at the General Secretariat of the notice of denunciation". It is noteworthy that Article 39/5 of the Treaty allows the state parties to denounce the Treaty only after 31 January 2021.

120 The 2008 Treaty of the Benelux Union, art. 1.

121 The 2008 Treaty of the Benelux Union, art. 2/1.

122 The 2008 Treaty of the Benelux Union, art. 2/2.

123 For an extensive analysis of the process aimed at a fully integrated Benelux Union, see Biscop, Sven / Coelmont, Jo / Drent, Margriet / Zandee, Dick. The Future of the Benelux Defence Cooperation, Netherlands Institute of International Relations, The Hague, 2013; Drent, Margriet / Homan, Kees / Zandee, Dick. Bold Steps in Multinational Cooperation: Taking European Defence Forward, Netherlands Institute of International Relations, The Hague, 2013; Drent, Margriet. Sovereignty, Parliamentary Involvement and European Defence Cooperation, Netherlands Institute of International Relations, The Hague, 2014; Drent, Margriet / Zandee, Dick / Casteleijn, Lo. Defence Cooperation in Clusters: Identifying the Next Steps, Netherlands Institute of International Relations, The Hague, 2014; van Nimwegen, Stephan. "The Need for the Netherlands and Belgium to Further Integrate Police Cooperation: An Example for Europe?", New Journal of European Criminal Law, vol. 8, no. 3, 2017, pp. 323-333; Venema, Agnes. "The Sum of All Friends: Improving Cross-border Intelligence Sharing in Europe - The Case of the Benelux", The International Journal of Intelligence, Security, and Public Affairs, vol. 22, no. 1, 2020, pp. 5-19.

124 For more details on the confederal relationship between Liechtenstein and Switzerland, see Kolçak, "Associate Statehood...", pp. 48-51; Veenendaal, Wouter. "A Big Prince in a Tiny Realm: Smallness, Monarchy, and Political Legitimacy in the Principality of Liechtenstein”, Swiss Political Science Review, vol. 21, no. 2, 2015, pp. 333-349. 
is likely for them to change their attitudes towards the minority demand because the number of secessionist national minorities is gradually increasing, resulting in many secession-specific constitutional issues. This circumstance would eventually urge sovereign states to resolve such issues in the name of protecting their constitutional orders.

According to this article, sovereign states would take into account the confederal form of governance in finding permanent resolutions to their secession-related minority questions. It is possible for secessionist national minorities to establish their sovereign states via confederal settlements. Moreover, these settlements would provide certain opportunities for separatist minorities and their host states to construct common unions, allowing them to protect and advance their constitutional links. Furthermore, the preserved and developed links would ultimately stimulate confederal allies - national minorities and their host states - to turn their unions into federations or unitary states in the long run.

\section{REFERENCES}

ABUSHOV, Kavus. “Autonomy as a Possible Solution to Self-determination Disputes: Does It Really Work?”, International Journal on Minority and Group Rights, vol. 22, no. 2, 2015, pp. 182-201.

ADAM, Elisanda. "Self-Determination and the Use of Referendums: The Case of Scotland", International Journal of Politics, Culture, and Society, vol. 27, no. 1, 2014, pp. 47-66.

ANDREU, Josep. "Constitution and Referendum on Secession in Catalonia", Claims for Secession and Federalism: A Comparative Study with a Special Focus on Spain, edited by Alberto López-Basaguren and Leire Escajedo San-Epifanio, Springer, New York, 2019, pp. 405-422.

ANTONIĆ, Slobodan. "Could a Confederation Have Saved Yugoslavia?", Nationalities Papers: The Journal of Nationalism and Ethnicity, vol. 25, no. 3, 1997, pp. 469-479.

ANTUNES, Sandrina; LOUGHLIN, John. "The European Union, Subnational Mobilization and State Rescaling in Small Unitary States: A Comparative Analysis", Regional \& Federal Studies, vol. 30, no. 2, 2020, pp. 121-136.

ASHCROFT, Richard; BEVIR, Mark. "Pluralism, National Identity and Citizenship: Britain after Brexit", The Political Quarterly, vol. 87, no. 3, 2016, pp. 355-359.

BARKEY, Karen; GAVRILIS, George. "The Ottoman Millet System: Non-Territorial Autonomy and its Contemporary Legacy", Ethnopolitics, vol. 15, no. 1, 2016, pp. 24-42.

BARTKUS, Ona. The Dynamic of Secession, Cambridge University Press, Cambridge, 1999.

BELKAHLA, Mehdi. Benelux Court of Justice, Max Planck Institute, Luxembourg, 2017.

BENEDIKTER, Thomas. The World's Modern Autonomy Systems: Concepts and Experiences of Regional Territorial Autonomy, EURAC Institute of Minority Rights, Bolzano, 2009.

BISCOP, Sven; COELMONT, Jo; DRENT, Margriet; ZANDEE, Dick. The Future of the Benelux Defence Cooperation, Netherlands Institute of International Relations, The Hague, 2013.

BORROWS, John. "Landed Citizenship: Narratives of Aboriginal Political Participation", Citizenship in Diverse Societies, edited by Will Kymlicka and Wayne Norman, Oxford University Press, Oxford, 2000, pp. 326-342.

BOULDEN, Jane; KYMLICKA, Will. "Introduction", International Approaches to Governing Ethnic Diversity, edited by Jane Boulden and Will Kymlicka, Oxford University Press, New York, 2015, pp. 1-21.

BOYLAN, Brandon; TURKINA, Ekaterina. "Calling on Europe? Secessionist Political Parties and Their Communications to the European Union”, Journal of Common Market Studies, vol. 57, no. 6, 2019, pp. 1310-1332.

BROOKS, Libby. "Sturgeon Demands Independence Referendum Powers be Devolved", The Guardian, (19.12.2019), $\quad$ https://www.theguardian.com/politics/2019/dec/19/nicola-sturgeon-requests-independencereferendum-powers, (Accessed on: 23.09.2020).

BUCHANAN, Allen. Secession: The Morality of Political Divorce from Fort Sumter to Lithuania and Quebec, Westview Press, Boulder, 1991.

BULLOCK, Steve. "What Representation Would an Independent Scotland Have in the EU?”, An Independent Scotland in the EU: Issues for Accession, edited by Kirsty Hughes, Scottish Centre on European Relations Publication Office, Edinburgh, 2020, pp. 20-22. 
BURSENS, Peter; CRUM, Ben. "The Benelux Countries: How Politicization Upset a Pro-Integration Coalition", National Politics and European Integration: From the Constitution to the Lisbon Treaty, edited by Maurizio Carbone, Edward Edgar Publishing, Cheltenham, 2010, pp. 144-163.

CAPOTORTI, Francesco. Study on the Rights of Persons Belonging to Ethnic, Religious and Linguistic Minorities, Official Publications of the United Nations, New York, 1979.

CARRELL, Severin. "Scottish Parliament Votes for Second Independence Referendum”, The Guardian, (28.03.2017), $\quad$ https://www.theguardian.com/politics/2017/mar/28/scottish-parliament-votes-for-secondindependence-referendum-ni-cola-sturgeon, (Accessed on: 25.09.2020).

CASIER, Tom. "The Bilateral Relations of the Benelux Countries with Russia: Between Rhetorical EU Engagement and Competitive Business Interests", Journal of Contemporary European Studies, vol. 19, no. 2, 2011, pp. 237-248.

CASTILLO, Antonio. "State Integration and Disintegration within the European Union: Regarding the Purported Secession of Catalonia and its Hypothetical Membership of the EU", Claims for Secession and Federalism: A Comparative Study with a Special Focus on Spain, edited by Alberto López-Basaguren and Leire Escajedo SanEpifanio, Springer, New York, 2019, pp. 563-574.

COGEN, Marc. An Introduction to European Intergovernmental Organizations, Ashgate, Surrey, 2015.

COGGINS, Bridget. "Friends in High Places: International Politics and the Emergence of States from Secessionism”, International Organization, vol. 65, no.3, 2011, pp. 433-468.

CONNOLLY, Christopher. "Independence in Europe: Secession, Sovereignty, and the European Union”, Duke Journal of Comparative and International Law, vol. 24, no. 1, 2013, pp. 51-105.

CORRAL, Benito; FREIJEDO, Francisco. "Constitutionalizing Secession in Order to Harmonize Constitutionality and Democracy in Territorial Decentralized States Like Spain", Claims for Secession and Federalism: A Comparative Study with a Special Focus on Spain, edited by Alberto López-Basaguren and Leire Escajedo San-Epifanio, Springer, New York, 2019, pp. 265-285.

CRAWFORD, James. "The Criteria for Statehood in International Law", British Yearbook of International Law, vol. 48, no. 1, 1976, pp. 93-182.

CRAWFORD, James. The Creation of States in International Law, $2^{\text {nd }}$ edition, Clarendon Press, Oxford, 2006.

CROWCROFT, Orlando. "Scottish Independence Referendum: Sturgeon Says 'Democracy will Prevail' after New Vote Refused”, Euronews, (14.01.2020), https:/www.euronews.com/2020/01/14/democracy-will-prevail-sayssturgeon-after-johnson-refuses-second-scottish-referendum, (Accessed on: 27.08.2020).

ÇETIN, Şerife. "EU Response on Catalonia Reveals Fears of Separatism”, Anadolu Agency, (11.10.2017), https://www.aa.com.tr/en/europe/eu-response-on-catalonia-reveals-fears-of-separatism/933025, (Accessed on 24.09.2020).

DARDANELLI, Paolo; MITCHELL, James. “An Independent Scotland? The Scottish National Party’s Bid for Independence and its Prospects”, The International Spectator: Italian Journal of International Affairs, vol. 49, no. 3, 2014, pp. 88-105.

DAVIDSON, Jenni. “Independence Referendum must be 'Legal and Legitimate', Nicola Sturgeon Emphasises in Brexit Day Speech”, Holyrood, (31.01.2020), https://www.holy-rood.com/news/view-independence-referendummust-be-legal-and-legitimate-nicola-sturge-on-emphas_15048.htm, (Accessed on: 20.09.2020).

DE VRIES, Jochem. "Venturing into Unknown Territory: The Preparation and Formulation of the Second Benelux Structural Outline”, European Planning Studies, vol. 16, no. 6, 2008, pp. 853-876.

DICKIE, Mure. "SNP 'Resets' Plans for Second Scottish Independence Referendum”, Financial Times, (27.06.2017), https://www.ft.com/content/84e08f70-b852-3f95-9619-279fc5b93-683, (Accessed on: 24.09.2020).

DODDS, Anneliese. "Why People Voted to Leave and What to Do Now: A View from the Doorstep", The Political Quarterly, vol. 87, no. 3, 2016, pp. 360-364.

DRENT, Margriet. Sovereignty, Parliamentary Involvement and European Defence Cooperation, Netherlands Institute of International Relations, The Hague, 2014.

DRENT, Margriet; HOMAN, Kees; ZANDEE, Dick. Bold Steps in Multinational Cooperation: Taking European Defence Forward, Netherlands Institute of International Relations, The Hague, 2013.

DRENT, Margriet; ZANDEE, Dick; CASTELEIJN, Lo. Defence Cooperation in Clusters: Identifying the Next Steps, Netherlands Institute of International Relations, The Hague, 2014. 
DUCHÁČEK, Ivo. "Consociations of Fatherlands: The Revival of Confederal Principles and Practices", Publius: The Journal of Federalism, vol. 12, no. 4, 1982, pp. 129-177.

DUCHÁČEK, Ivo. "Consociational Cradle of Federalism”, Publius: The Journal of Federalism, vol. 15, no. 2, 1985, pp. 35-49.

DUMIEŃSKI, Zbigniew. Microstates as Modern Protected States: Towards a New Definition of MicroStatehood, Institute of International Affairs, Auckland, 2014.

ELAZAR, Daniel. "Confederation and Federal Liberty", Publius: The Journal of Federalism, vol. 12, no. 4, 1982, pp. 1-14.

ELAZAR, Daniel. Exploring Federalism, University of Alabama Press, Tuscaloosa, 1987.

ELAZAR, Daniel. Federalism: An Overview, Human Sciences Research Council Publishers, Pretoria, 1995.

ELAZAR, Daniel. "From Statism to Federalism: A Paradigm Shift", Publius: The Journal of Federalism, vol. 25, no. 2, 1995, pp. 5-18.

ELAZAR, Daniel. "Introduction: Using Federalism Today”, International Political Science Review, vol. 17, no. 4, 1996, pp. 349-351.

ELAZAR, Daniel. “Contrasting Unitary and Federal Systems", International Political Science Review, vol. 18 , no. 3, 1997, pp. 237-251.

ELLYATT, Holly. "If Catalonia Goes Independent, These Places Could be Next", CNBC, (06.10.2017), https://www.cnbc.com/2017/10/06/if-catalonia-goes-independent-these-places-could-be-next.html, (Accessed on: 25.09.2020).

ENE, Angela-Mihaela. "The Integrative Process of the European Union from the Perspective of IntraCommunity Secessionist Movements”, European Integration Realities and Perspectives, vol. 14, no. 1, 2019, pp. 313318.

GHAI, Yash. "Ethnicity and Autonomy: A Framework for Analysis", Autonomy and Ethnicity: Negotiating Competing Claims in Multi-Ethnic States, Cambridge University Press, Cambridge, 2000, pp. 1-26.

GOLDMAN, Olivia. "The Need for an Independent International Mechanism to Protect Group Rights: A Case Study of the Kurds", Tulsa Journal of Comparative and International Law, vol. 2, no. 1, 1994, pp. 45-89.

GOODWIN, Matthew; HEATH, Oliver. "The 2016 Referendum, Brexit and the Left Behind: An AggregateLevel Analysis of the Result", The Political Quarterly, vol. 87, no. 3, 2016, pp. 323-332.

GRAY, Caroline. Territorial Politics and the Party System in Spain: Continuity and Change since the Financial Crisis, Routledge, London, 2020.

GRIFFITHS, Ryan. "Between Dissolution and Blood: How Administrative Lines and Categories Shape Secessionist Outcomes", International Organization, vol. 69, no. 3, 2015, pp. 731-751.

GROENENDIJK, Kees. "Reinstatement of Controls at the Internal Borders of Europe: Why and Against Whom?", European Law Journal, vol. 10, no. 2, 2004, pp. 150-170.

HANNUM, Hurst. Autonomy, Sovereignty and Self-determination: The Accommodation of Conflicting Rights, University of Pennsylvania Press, Philadelphia, 1996.

HEINTZE, Hans. "On the Legal Understanding of Autonomy", Autonomy: Applications and Implications, edited by Markku Suksi, Kluwer Law International, The Hague, 1998, pp. 7-32.

HENLEY, Jon; SHEEHY, Finbarr; SWANN, Glenn; FENN, Chris. "Beyond Catalonia: Pro-independence Movements in Europe", The Guardian, (27.10.2017), https://www.theguardian.com/world/nginteractive/2017/oct/27-/beyond-catalonia-pro-independence-movements-in-europe-map, (Accessed on: 25.09.2020).

HOBOLT, Sara. "The Brexit Vote: A Divided Nation, a Divided Continent", Journal of European Public Policy, vol. 23, no. 9, 2016, pp. 1259-1277.

ICHIJO, Atsuko. "Sovereignty and Nationalism in the Twenty-first Century: The Scottish Case", Ethnopolitics, vol. 8, no. 2, 2009, pp. 155-172.

JEFFERSON, Rodney; MORALES, Alex. "Scotland's Leader Warns Johnson He 'can't Deny Democracy", Bloomberg, (10.02.2020), https://www.bloomberg.com/news/articles/2020-02-10/scotlands-leader-warns-borisjohnson-he-can-t-deny-democracy, (Accessed on: 23.09.2020).

JONES, Erik. The Benelux Countries: Identity and Self-Interest, John Hopkins Bologna Centre, Bologno, 2003.

KEATING, Michael. "The Scottish Independence Referendum and After", Revista d'Estudis Autonòmics $i$ Federals, vol. 21, no. 1, 2015, pp. 73-98. 
KEATING, Michael. "Is a Theory of Self-Determination Possible?", Ethnopolitics, vol. 18, no. 3, 2019 , pp. 315-323.

KOEV, Dan. "Why Ethnic Parties? A New Theory of Ethnic Minority Political Strategy in Europe", Nations and Nationalism, vol. 25, no. 1, 2019, pp. 229-297.

KOLÇAK, Hakan. "Associate Statehood for Scotland as the Way to Stay in both the United Kingdom and the European Union: The Liechtenstein Example”, Romanian Journal of European Affairs, vol. 17, no. 1, 2017, pp. 4058.

KOLÇAK, Hakan. "From Unionism to Secessionism: A Comprehensive Analysis of Contemporary Catalan Politics", Journal of Society and Politics, vol. 12, no. 1, 2017, pp. 25-52.

KOLÇAK, Hakan. "Multinational Federalism, Accommodation Policies and State Models: The Management of National Minorities”, 2. International 19 May Innovative Scientific Approaches Congress Proceedings, 27-29 December 2019, Samsun, edited by Iasha Bekadze and Samira Khadhraoui Ontunç, Farabi Publications, Gaziantep, 2019, pp. 1304-1333.

KOLÇAK, Hakan. "Ongoing Unionism: A Comprehensive Analysis of Galicia via Constitutional and Legal Perspectives”, Selected Studies on Social Science, edited by Özlem Kaya, Iksad Publications, Ankara, 2020 , pp. 3-42.

KOLÇAK, Hakan. "Unionist Wales: A Comprehensive Analysis of the Welsh Devolved Region via Constitutional and Legal Perspectives", Public Administrative Studies, edited by Sefer Y1lmaz, Akademisyen Publishing House, Ankara, 2020, pp. 1-21.

KRAUS, Peter. “Democracy's Challenge: Nordic Minority Politics in the European Context”, The Challenge of Minority Integration: Politics and Policies in the Nordic Nations, edited by Peter Kraus and Peter Kivisto, De Gruyter, Berlin 2015, pp. 38-51.

KYMLICKA, Will. “The Internationalization of Minority Rights”, International Journal of Constitutional Law, vol. 6, no. 1, 2008, pp. 1-32.

KYMLICKA, Will. "Categorizing Groups, Categorizing States: Theorizing Minority Rights in a World of Deep Diversity”, Ethnic \& International Affairs, vol. 24, no. 3, 2009, pp. 371-388.

KYMLICKA, Will. "The Rise and Fall of Multiculturalism? New Debates on Inclusion and Accommodation in Diverse Societies”, International Social Science Journal, vol. 61, no. 199, 2010, pp. 97-105.

KYMLICKA, Will. "Beyond the Indigenous/Minority Dichotomy", Reflection on the UN Declaration on the Rights of Indigenous Peoples, edited by Stephen Allen and Alexandra Xanthaki, Hart Publishing, Oxford, 2011, pp. 183-208.

KYMLICKA, Will. "The Essentialist Critique of Multiculturalism: Theory, Policies and Ethos", Multiculturalism Rethought: Essays in Honour of Bhikhu Parekh, edited by Tariq Modood and Varun Uberoi, Edinburgh University Press, Edinburgh, 2015, pp. 219-245.

KYMLICKA, Will; NORMAN, Wayne. "Citizenship in Culturally Diverse Societies: Issues, Contexts and Concepts", Citizenship in Diverse Societies, edited by Will Kymlicka and Wayne Norman, Oxford University Press, Oxford, 2000, pp. 1-41.

KYMLICKA, Will; RAVIOT, Jean-Robert; LEE, Steve. "Living Together: International Aspects of Federal Systems”, Canadian Foreign Policy Journal, vol. 5, no. 1, 1997, pp. 1-50.

LAPIDOTH, Ruth. Autonomy: Flexible Solutions to Ethnic Conflicts, United States Institute for Peace Press, Washington, 1997.

LEARMONTH, Andrew. "Boris Johnson Publishes Response to SNP's Section 30 Request”, The National, (14.01.2020), https://www.thenational.scot/news/18158724.johnson-publishes-response-snps-section-30-request, (Accessed on: 23.09.2020).

LÉGARÉ, André; SUKSI, Markku. "Rethinking the Forms of Autonomy at the Dawn of the 21st Century", International Journal on Minority and Group Rights, vol. 15, no. 2, 2008, pp. 143-155.

LEVY, Jacob. “Three Modes of Incorporating Indigenous Law”, Citizenship in Diverse Societies, edited by Will Kymlicka and Wayne Norman, Oxford University Press, Oxford, 2000, pp. 297-325.

LISTER, Frederick. The European Union, the United Nations, and the Revival of Confederal Governance, Greenwood Press, London, 1996.

LOCK, Tobias. "Negotiating EU Accession: Lessons for an Independent Scotland", An Independent Scotland in the EU: Issues for Accession, edited by Kirsty Hughes, Scottish Centre on European Relations Publication Office, Edinburgh, 2020, pp. 9-12. 
LOUGHLIN, John; ANTUNES, Sandrina. "State Rescaling and a 'Europe of the Regions' in Small Unitary States: A Damp Squib?”, Regional \& Federal Studies, vol. 30, no. 2, 2020, pp. 303-321.

MACCORMICK, Neil. Questioning Sovereignty: Law, State and Practical Reason, Oxford University Press, Oxford, 1999.

MACNAB, Scott. "Scottish Parliament Backs Holding Indyref2 Vote This Year”, The Scotsman, (29.01.2020), https://www.scotsman.com/news/scottish-news/scottish-parliament-backs-holding-indyref2-vote-year-1395741,

(Accessed on: 27.08.2020).

MAES, Ivo; VERDUN, Amy. "Small States and the Creation of EMU: Belgium and the Netherlands, Pacesetters and Gate-keepers”, Journal of Common Market Studies, vol. 43, no. 2, 2005, pp. 327-348.

MAS, Joaquin. "Secession and Federalism: The Spanish Case", Claims for Secession and Federalism: A Comparative Study with a Special Focus on Spain, edited by Alberto López-Basaguren and Leire Escajedo SanEpifanio, Springer, New York, 2019, pp. 389-404.

MASTROMARINO, Anna. "Secessionist Claims in a Federal System: The Belgian Case", Claims for Secession and Federalism: A Comparative Study with a Special Focus on Spain, edited by Alberto López-Basaguren and Leire Escajedo San-Epifanio, Springer, New York, 2019, pp. 221-232.

MAUTNER, Menachem. "West Bank and Gaza: The Case for Associate Statehood", Yale Journal of International Law, vol. 6, no. 2, 1981, pp. 297-360.

MCEWEN, Nicola. "Devolution and Alignment with EU Laws", An Independent Scotland in the EU: Issues for Accession, edited by Kirsty Hughes, Scottish Centre on European Relations Publication Office, Edinburgh, 2020, pp. 13-16.

MCGARRY, John. “Asymmetry in Federations, Federacies and Unitary States”, Ethnopolitics, vol. 6, no. 1, 2007, pp. 105-116.

MEER, Nasar. "Looking up in Scotland? Multinationalism, Multiculturalism and Political Elites", Ethnic and Racial Studies, vol. 38, no. 9, 2015, pp. 1477-1496.

MEIJER, Erik. “The Radical Left in Benelux”, Socialism and Democracy, vol. 29, no. 3, 2015, pp. 71-80.

MORICE, Sarah. "2017 Year in Review: Europe's Secessionist Movements", TRT World, (25.12.2017), https://www.trtworld.com/europe/2017-year-in-review-europe-s-secessionist-movements-13595, (Accessed on: 25.09.2020).

MULLEN, Tom. "Brexit and the Territorial Governance of the United Kingdom", Contemporary Social Science, vol. 14, no. 2, 2019, pp. 276-293.

MÜLLER-PLOTNIKOW, Sabrina. "Beyond Catalonia: Separatist Movements in Western Europe", Deutsche Welle, (30.09.2017), $\quad$ https://www.dw.com/en/beyond-catalonia-separatist-movements-in-western-europe/a40761144, (Accessed on: 24.09.2020).

NORDQUIST, Kjell. “Autonomy as a Conflict-Solving Mechanism: An Overview”, Autonomy: Applications and Implications, edited by Markku Suksi, Kluwer Law International, The Hague, 1998, pp. 59-77.

NUTT, Kathleen. "Scotland could Rejoin EU Four-Five Years after Indy, Expert Says", The National, (22.05.2020), https://www.thenational.scot/news/18469817.scotland-rejoin-eu-four-five-years-indy-expert-says, (Accessed on: 18.09.2020).

OLAUSSON, Pär. Autonomy and Islands, a Global Study of the Factors that Determine Island Autonomy, Åbo Akademi University Press, Åbo, 2007.

PAVKOVIC, Aleksandar; RADAN, Peter. Creating New States: Theory and Practice of Secession, Ashgate, Hampshire, 2007.

PERRY, Valery. "Constitutional Reform in Bosnia and Herzegovina: Does the Road to Confederation Go through the EU?", International Peacekeeping, vol. 22, no. 5, 2015, pp. 490-510.

RAJA, Irfan. "Can the United Kingdom Hold its Union?", Daily Sabah, (21.02.2020), https://www.dailysabah.com/op-ed/2020/02/21/can-the-united-kingdom-hold-its-union, (Accessed on: 24.09.2020).

READ, Carly. "Scottish Parliament to Keep Flying EU Flag after Brexit in Huge Snub to Referendum Result", The Express, (29.01.2020), https://www.express.co.uk/news/politics/1-23-5177/scottish-parliament-eu-flag-brexitday-snp-nicola-sturgeon-latest, (Accessed on: 26.09.2020).

REZVANI, David. Surpassing the Sovereign State: The Wealth, Self-rule and Security Advantages of Partially Independent Territories, Oxford University Press, Oxford, 2014. 
REZVANI, David. "Partial Independence Beats Full Independence”, Territory, Politics, Governance, vol. 4, no. 3, 2015, pp. 269-296.

ROBERTSON, Angus. "A Whopping Majority Believes Scotland has Right to Decide over Indyref2”, The Scotsman, (28.01.2020), https://www.scotsman.com/news/politics/scottish-independence/whopping-majoritybelieves-scotland-has-right-decide-over-indyref2-angus-r-obertson-1376832, (Accessed on: 25.09.2020).

SCHREUER, Milan. "Catalan Separatists Want Independence. Who Else?", The New York Times, (17.12.2017), https://www.nytimes.com/2017/12/17/world/europe/catalonia-independence-europe.html, (Accessed on: 26.09.2020).

SCHULTE, Felix. Conflict Regulation through Self-Rule: Success Factors of Territorial Autonomy Systems, Aland Islands Peace Institute, Mariehamn, 2015.

SILVERSTRÖM, Sören. "The Competence of Autonomous Entities in the International Arena: With Special Reference to the Aland Islands in the European Union", International Journal on Minority and Group Rights, vol. 15, no. 2, 2008, pp. 259-271.

STEPAN, Alfred. "A Revised Theory of Federacy and a Case Study of Civil War Termination in Aceh, Indonesia", Power Sharing in Deeply Divided Places, edited by Joanne McEvoy and Brendan O'Leary, University of Pennsylvania Press, Philadelphia, 2013, pp. 231-252.

STEVENS, Michael. "Asymmetrical Federalism: The Federal Principle and the Survival of the Small Republic", Publius: The Journal of Federalism, vol. 7, no. 4, 1977, pp. 177-203.

STURGEON, Nicola. "Nicola Sturgeon Responds to the Brexit Vote - Read her Speech in Full", Holyrood, (24.06.2016), https://www.holyrood.com/articles/inside-politics/\%20nicola-stur-geon-responds-brexit-vote-read-herspeech-full, (Accessed on: 10.09.2020).

STURGEON, Nicola. "We've Made a Real Difference: Nicola Sturgeon Reflects on 20 Years of Devolution”, Yes, (01.07.2019), https://www.yes.scot/weve-made-a-real-difference-nicola-sturgeon-reflects-on-20-years-ofdevolution/, (Accessed on: 25.09.2020).

SUKSI, Markku. Sub-state Governance through Territorial Autonomy: A Comparative Study in Constitutional Laws of Powers, Procedures and Institutions, Springer-Verlag, Heidelberg, 2011.

SUKSI, Markku. "Explaining the Robustness and Longevity of the Aland Example in Comparison with Other Autonomy Solutions”, International Journal on Minority and Group Rights, vol. 20, no. 1, 2013, pp. 51-66.

SWAN, Brown; CETRA, Daniel. "Why Stay Together? State Nationalism and Justifications for State Unity in Spain and the UK", Nationalism and Ethnic Politics, vol. 26, no. 1, 2020, pp. 46-65.

TIERNEY, Stephen. "Legal Issues Surrounding the Referendum on Independence for Scotland", European Constitutional Law Review, vol. 9, no. 3, 2013, pp. 359-390.

TIERNEY, Stephen. "Reclaiming Politics: Popular Democracy in Britain after the Scottish Referendum", The Political Quarterly, vol. 86, no. 2, 2015, pp. 226-233.

TKACIK, Michael. "Characteristics of Forms of Autonomy", International Journal on Minority and Group Rights, vol. 15, no. 2, 2008, pp. 369-401.

TORRES, Diego. “Europe's Separatists Feel Catalan Chill”, Politico, (04.09.2018), https://www.politico.eu/article/cata-lan-chill-for-european-separatist-movements-aland-isla-nds-south-tyrol/,

(Accessed on: 26.09.2020).

VAN NIMWEGEN, Stephan. "The Need for the Netherlands and Belgium to Further Integrate Police Cooperation: An Example for Europe?”, New Journal of European Criminal Law, vol. 8, no. 3, 2017, pp. 323-333.

VEENENDAAL, Wouter. "A Big Prince in a Tiny Realm: Smallness, Monarchy, and Political Legitimacy in the Principality of Liechtenstein”, Swiss Political Science Review, vol. 21, no. 2, 2015, pp. 333-349.

VENEMA, Agnes. "The Sum of All Friends: Improving Cross-border Intelligence Sharing in Europe - The Case of the Benelux", The International Journal of Intelligence, Security, and Public Affairs, vol. 22, no. 1, 2020 , pp. 5-19.

WAGNER, Andrea; MARIN, Jianna; KROQI, Dorian. "The Catalan Struggle for Independence and the Role of the European Union”, Regional Science Policy \& Practice, vol. 11, no. 5, 2019, pp. 787-803.

WATTS, Ronald. "Federalism, Federal Political Systems, and Federations", Annual Review of Political Science, vol. 1, no. 1, 1998, pp. 117-137. 
WEBSTER, Laura. "Unionists Furious as EU Boss Indicates Indy Scotland can Rejoin”, The National, (20.05.2020), https://www.thenational.scot/news/18462298.unionists-furious-eu-boss-indicates-indy-scot-land-canrejoin, (Accessed on: 23.08.2020).

WELLER, Marc. "Introduction”, Asymmetric Autonomy and the Settlement of Ethnic Conflicts, edited by Marc Weller and Katherine Nobbs, University of Pennsylvania Press, Philadelphia, 2010, pp. 1-13.

WIRT, Frederick. "The Tenacity of Confederacy: Local Service Agreements in the Family of Governments", Publius: The Journal of Federalism, vol. 12, no. 4, 1982, pp. 103-127.

WITLOX, Frank; DULLAERT, Wout; JOURQUIN, Bart. "Fostering Transport and Logistics Research in the Benelux Countries", Transportation Planning and Technology, vol. 30, no. 4, 2007, pp. 325-329.

WOLFF, Stefan. "Post-Conflict State Building: The Debate on Institutional Choice", Third World Quarterly, vol. 32, no. 10, 2011, pp. 1777-1802.

WOLFF, Stefan. "Conflict Management in Divided Societies: The Many Uses of Territorial Self-Governance", International Journal on Minority and Group Rights, vol. 20, no. 1, 2013, pp. 27-50.

WOUTERS, Jan; VIDAL, Maarten. Towards a Rebirth of Benelux?, Leuven Centre for Global Governance Studies, Leuven, 2008.

ZONNEVELD, Wil; FALUDI, Andreas. "Vanishing Borders: The Second Benelux Structural Outline", Built Environment, vol. 23, no. 1, 1997, pp. 4-13.

ZULEEG, Fabian. "Transition from the UK and to the EU", An Independent Scotland in the EU: Issues for Accession, edited by Kirsty Hughes, Scottish Centre on European Relations Publication Office, Edinburgh, 2020 , pp. 17-19. 